scientific aspects of agriculture will discuss the vernalization of crops, a limitation in the varieties of plants in cultivation and the protection of producers of selected seeds, artificial fertilization in the im. provement of livestock, animal nutrition and other subjects. Social and educational questions will include the teaching of agricultural economics, broadcasting in the service of agriculture and health and hygien $\theta$ in the rural home, a subject to which the National Federation of Women's Institutes (England) will make the principal contribution. Further particulars may be obtained from the Secretary, British Corresponding Committee, International Congress of Agriculture, 10 Doughty Street, London, W.C.l.

\section{An International Exhibition of Photography}

LNDER the chairmanship of Gustave Fassin, of the Bausch and Lomb Scientific Bureau, Rochester, New York, a committee has been appointed to secure and arrange exhibits for the International Exhibition of Applied and Scientific Photography to be held in the Rundell Memorial Building at Rochester, New York, in March, under the auspices of the local section of the Photographic Society of America. This new and beautiful civic building has exceptional facilities for showing both pictures and apparatus. Men of science working in any of the following fields are invited to send exhibits to the Secretary. Mr. C. B. Neblette, Rochester Athenæum and Mechanics Institute, Rochester, New York: astronomy, meteorology, light-sensitive substances; photomicrography, microphotography, metallography; X-ray spectrography ; cosmic ray photography and theoretical physics; press photography; high-speed photography; technique of colour photography; photography by invisible radiation; aerial photography.

\section{Awards of the Geological Society}

The Geological Society has made the following awards: Wollaston Medal to Prof. Waldemar Lindgren of the Massachusetts Institute of Techno$\operatorname{logy}$, for his researches concerning the mineral structure of the earth, and especially concerning the problems of mesasomatism, contact ore deposits and the application of physical chemistry to ore deposition; Murchison Medal to Dr. L. J. Spencer, in recognition of the value of his original contributions to mineralogical science and of his services to the publication of mineralogical literature; Lyell Medal to Mr. L. Richardson, for his contributions to the geology of the Jurassic rocks of Great Britain; Bigsby Medal to Prof. C. E. Tilley, in recognition of the value of his researches in petrological science, especially in the petrology of the metamorphic rocks; Wollaston Fund to Dr. D. Parkinson; Murchison Fund to Mr. S. H. Straw; a moiety of the Lyell Fund to Mr. J. F. Jackson; another moiety of the Lyell Fund to Miss M. E. Tomlinson.

\section{Announcements}

DR. E. J. BUTLER, secretary of the Agricultural Research Council; Dr. J. B. Conant, president of Harvard University ; and Lord Hailey, director of the African Research Survey, have been elected members of the Athenæum under the provisions of Rule II of the Club, which empowers the annual election by the committee of a certain number of persons of distinguished eminence in science, literature, the arts, or for public service.

Mr. J. RAmsвotrom, keeper of botany at the British Museum (Natural History), and a secretary to the Linnean Society of London, who is known for his mycological researches, has been elected an honorary member of the Quekett Microscopical Club.

Mr. Richmond T. Zock, of the U.S. Weather Bureau, has been elected a foreign member of the Royal Meteorological Society.

The annual general meeting of the Association of Technical Institutions will be held in the Carpenters' Hall, Throgmorton Avenue, London, E.C.2, on February 26-27. On February 26, at 10.45 a.m., the incoming president, the Right Hon. Lord Kennet, will deliver the presidential address. Further information can be obtained from Dr. H. Schofield, Loughborough College, Loughborough, Leicestershire.

THE fourth International Grassland Congress will be held in Great Britain under the presidency of Prof. R. G. Stapledon on July 8-23. The Congress will meet first at Oxford and will then proceed to various places of topical interest including Leicester, Birmingham, Cirencester, Hereford, Aberystwyth, Newcastle and Edinburgh. Further information can be obtained from the Joint Secretaries, Agricultural Buildings, Aberystwyth.

THE Associated Grocery Manufacturers Association of America at the annual banquet on December 1 presented Dr. George R. Minot of Boston with the annual award for research in the field of health leading to the prevention of disease and the advancement of health. The presentation address was made by Dr. Morris Fishbein, editor of the Journal of the American Medical Association.

Dr. JoHN HowARD Northrop, of the Rockefeller Institute for Medical Research, Princeton, N.J., has been awarded the Charles Frederick Chandler Medal of Columbia University in recognition of his fundamental discoveries concerning bacteria, the constitution of protein and the chemistry of digestion. The medal was founded in 1910 in honour of Prof. Chandler, who taught at Columbia University and was a pioneer in industrial chemistry.

Dr. Davide Grordano, president of the Italian Society of the History of Medicine and Natural Sciences ; Dr. Bernhard Peyer, professor of palæonto. logy at Zurich; and Dr. Brouwer, professor of neuropathology at Amsterdam, have been elected members of the Leopold Caroline German Academy of Natural Philosophy at Halle. 